\title{
(2) OPEN ACCESS \\ SKAP2-BRAF fusion and response to an MEK inhibitor in a patient with metastatic melanoma resistant to immunotherapy
}

\author{
Sonya Minmin Chew @ ( ) Mairi Lucas, Michelle Brady, Catherine Margaret Kelly
}

Medical Oncology, Mater Misericordiae University Hospital, Dublin, Ireland

Correspondence to Professor Catherine Margaret Kelly; ckelly@mater.ie

Accepted 15 April 2021

Check for updates

(c) BMJ Publishing Group Limited 2021. Re-use permitted under CC BY-NC. No commercial re-use. See rights and permissions. Published by BMJ.

To cite: Chew SM, Lucas M, Brady $\mathrm{M}$, et al. BMJ Case Rep 2021;14:e238494. doi:10.1136/bcr-2020238494

\section{SUMMARY}

A woman in her 40s presented to the emergency department with headache and unintentional weight loss in September 2018. Investigations revealed a widely metastatic pan-negative melanoma of unknown primary. She had multiple lines of treatment including combination immunotherapy and chemotherapy. Nextgeneration sequencing identified an SKAP2-BRAF fusion protein, and she was commenced on an MEK inhibitor in September 2019 with a partial response seen on restaging scans after 6 weeks and a dramatic fall in her lactate dehydrogenase from $2248 \mathrm{IU} / \mathrm{L}$ to 576 IU/L. Unfortunately, the response was not maintained and she died from progression of her cancer in January 2020. SKAP2-BRAF fusions have a dimerisation domain that paradoxically activates the mitogen-activated protein kinase pathway, resulting in hyperproliferation if first-generation or second-generation BRAF inhibitors are used. Our knowledge is limited regarding the complex effects of targeted therapy in rare BRAF fusion proteins.

\section{BACKGROUND}

Melanoma is the fifth most common cancer in Ireland, with an incidence rate of 21 cases per 100 000 per year. Risk factors for melanoma include sun exposure, sunbed use, fair skin, increased moles and freckling, and a family history of melanoma. ${ }^{1}$ Cutaneous melanoma is classified according to its site of origin (epithelium vs non-epithelium), the level of cumulative solar damage and the frequency of mutations. Superficial spreading melanoma is the most common subtype (70\%), followed by nodular melanoma (15\%), lentigo maligna melanoma (10\%) and acral lentiginous melanoma $(<5 \%)$. Rare variants include amelanotic, spitzoid and desmoplastic melanoma. $^{2}$

Recurrent driver mutations at specific loci in BRAF, NRAS, KIT, GNAQ and GNA11 define clinically relevant molecular subsets of melanoma. KIT mutations are more frequent in mucosal melanomas and GNAQ/GNA11 mutations in uveal melanomas. Identifying these possible mutations is important to guide treatment and access targeted therapy. Up to $30 \%$ are 'pan-negative' for these recurrent mutations; however, $4 \%-8 \%$ of this pan-negative melanoma population may harbour a BRAF fusion. ${ }^{3}$ We present the case of a patient with metastatic melanoma with an SKAP2-BRAF fusion treated with the MEK inhibitor trametinib after progression on immunotherapy and chemotherapy.

\section{CASE PRESENTATION}

A woman in her 40 s presented to the emergency department with headache and unintentional weight loss in September 2018. Her only relevant background history was of resection of a giant congenital naevus on her back in her childhood. The patient did not meet the criteria for a screening MRI scan for neurocutaneous melanosis during her initial diagnosis of a giant congenital naevus as she was neurologically asymptomatic. ${ }^{4}$

\section{INVESTIGATIONS}

Staging CT scans showed widely metastatic disease with a lung mass and brain, liver and adrenal metastases. A lung biopsy confirmed a diagnosis of stage 4 melanoma of unknown primary that was negative for BRAF, NRAS, KIT, GNAQ and GNA11 mutations via immunohistochemistry and polymerase chain reaction (PCR) testing. Immunohistochemistry revealed positive staining of the neoplastic cells for Melan A and S100, which were consistent with metastatic malignant melanoma. Her lactate dehydrogenase (LDH) at diagnosis was $391 \mathrm{IU} / \mathrm{L}$.

Her risk factors for melanoma included fair skin and several moles under regular skin surveillance with the dermatology team. A repeat full skin examination and ocular examination did not elucidate the location of a primary melanoma.

\section{TREATMENT}

The patient received brain stereotactic radiation, followed by combination immunotherapy with ipilimumab $3 \mathrm{mg} / \mathrm{kg}$ and nivolumab $1 \mathrm{mg} / \mathrm{kg}$ q21/7 (3 weekly) for two cycles from November 2018. Ipilimumab is a CTLA inhibitor and nivolumab is a PD1 inhibitor which is a standard first-line immunotherapy treatment regime for metastatic melanoma. She developed progression of disease in December 2018, with an increase in index lung metastasis from $1.8 \mathrm{~cm}$ to $2.8 \mathrm{~cm}$ and new bilobar liver metastases ranging from $0.4 \mathrm{~cm}$ to $1.0 \mathrm{~cm}$, abnormal liver function tests and a rising LDH to $1448 \mathrm{IU} / \mathrm{L}$.

She proceeded to dacarbazine $1000 \mathrm{mg} / \mathrm{m}^{2} \mathrm{q} 21 / 7$ for six cycles with an initial response in February 2019 and a decrease in LDH to 238 IU/L. However, she had progression of the disease in May 2019 with the index lung metastasis increasing to $4.5 \mathrm{~cm}$ and the liver metastasis to $1.8 \mathrm{~cm}$ with an $\mathrm{LDH}$ of $1063 \mathrm{IU} / \mathrm{L}$. She then presented with confusion and was found to have an enlarging brain metastasis 


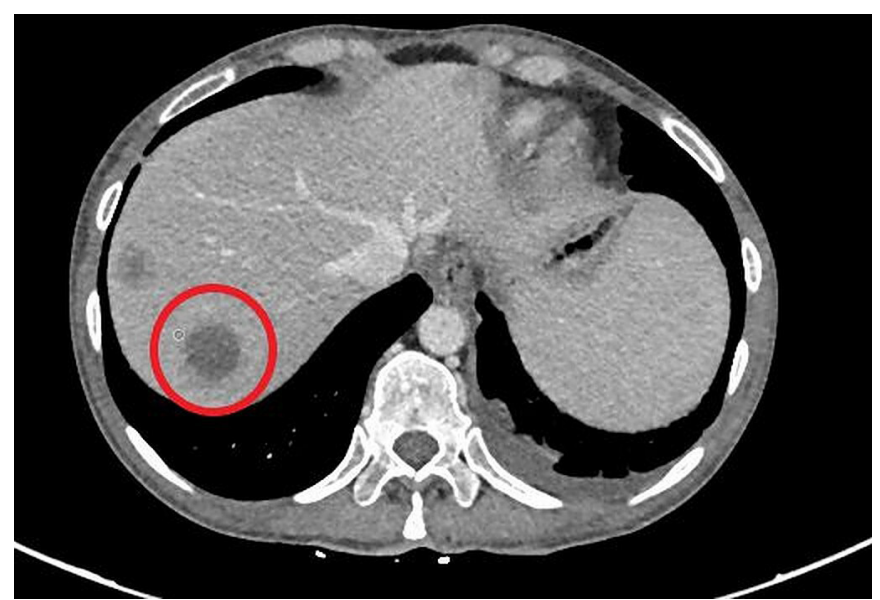

Figure 1 Liver lesions prior to commencing on an MEK inhibitor. Lactate dehydrogenase was $2248 \mathrm{IU} / \mathrm{L}$.

and underwent emergency resection followed by whole brain radiation.

On recovery, she was rechallenged with another immunotherapy PD1 inhibitor, pembrolizumab 400 mg q6/52 (6 weekly) from June 2019 for three cycles. However, her cancer progressed 3 months later into the brain, lungs, liver, skin and axillae, and the index lung metastasis increased to $5 \mathrm{~cm}$ and the liver metastasis to $2.4 \mathrm{~cm}$ with an LDH of $2248 \mathrm{IU} / \mathrm{L}$. She had no toxicity issues with her various lines of treatment other than fatigue.

Unfortunately, there were no clinical trials available. Metastatic tissue from the lung was sent for next-generation sequencing (NGS) (FoundationOne). A BRAF fusion protein was identified and she was commenced on an MEK inhibitor trametinib in September 2019.

\section{OUTCOME AND FOLLOW-UP}

On starting trametinib, there was a dramatic clinical improvement along with a fall in LDH from 2248 IU/L to $576 \mathrm{IU} / \mathrm{L}$, and she had a partial response seen on restaging scans after 6 weeks (figures 1 and 2). The response was not maintained and her cancer progressed radiologically and clinically within weeks of the initial response, with her LDH rising to $5011 \mathrm{IU} / \mathrm{L}$ in December 2019. She died from progression of her cancer in January 2020.

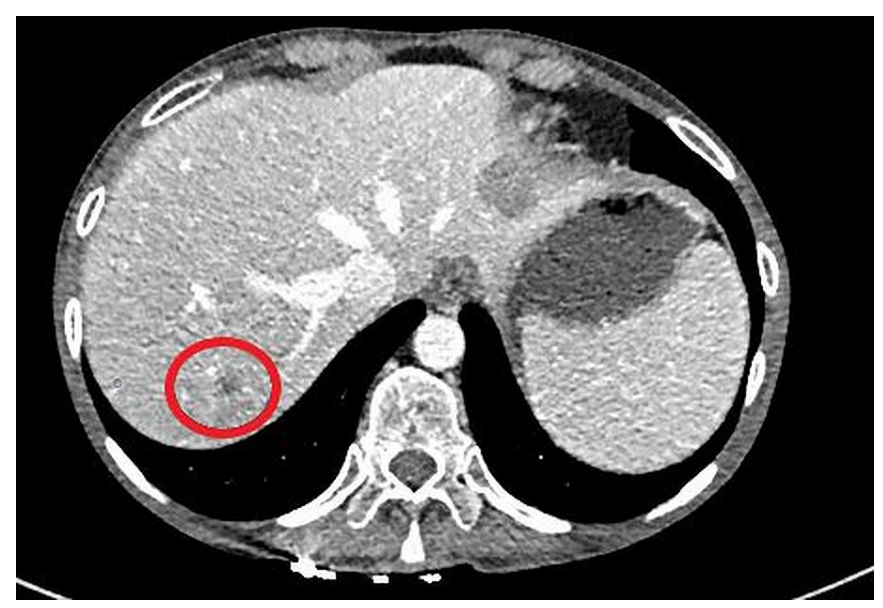

Figure 2 Improvement in liver lesions after a 6-week interval of commencing on an MEK inhibitor. Lactate dehydrogenase was $576 \mathrm{IU} / \mathrm{L}$.

\section{DISCUSSION}

Initial BRAF testing for this patient was via real-time PCR that identifies mutations at BRAF exon 11 and 15 only, which were not detected. NGS is a DNA sequencing technology that uses parallel sequencing of multiple small fragments of DNA to sequence an individual's genome. The aim of NGS testing is to identify actionable mutations that may unlock further treatment options and help predict treatment response. NGS allowed further sequencing of the patient's genome, thus enabling detection of the BRAF fusion.

Oncogenic BRAF fusions arise from genomic rearrangements, placing the 3' portion of the BRAF gene encoding the kinase domain at the $5^{\prime}$ position. This results in the loss of the autoinhibitory domain of BRAF and the expression of oncoproteins that are constitutively active. ${ }^{5}$

A recent review of the literature found that BRAF fusions are more prevalent in female patients with melanocytic tumours. They are early driver events and are often associated with spitzoid histopathology as seen in our patient. The median age at presentation with a BRAF fusion-associated melanoma was 39 years. ${ }^{6}$

Data comparing the various fusions' response to targeted treatment and mechanism of action are limited. ${ }^{7}$ Historically patients with non-V600 BRAF mutations tend to respond less well to BRAF/MEK inhibition, which may be due to these tumours harbouring alternative pathways of cellular activation. ${ }^{8}$ There is a suggestion that rare BRAF fusions may show responsiveness to BRAF and MEK inhibitors. ${ }^{9} 10$

A study that specifically looked at the SKAP2-BRAF fusion showed that the fusion partner contained a dimerisation domain. The presence of this dimerisation domain promoted paradoxical activation of the mitogen-activated protein kinase pathway and hyperproliferation in response to first-generation and secondgeneration BRAF inhibitors. This was the reason why our patient received MEK inhibitor alone, rather than a combination of BRAF and MEK inhibitors, which would be the standard practice in BRAF-mutated melanoma.

Preclinical in vivo and in vitro studies using cell lines harbouring this BRAF fusion protein have shown responses to

\section{Patient's perspective}

Perspective from patient's husband:

My wife had regular skin screening annually with several moles under follow-up until 2018. Though probably unconnected with the eventual diagnosis of metastatic melanoma, we both felt that perhaps something was missed in the early stages. The care she received thereafter was excellent.

\section{Learning points}

- Our knowledge is limited regarding the complex effects of targeted therapy in rare BRAF fusions.

- SKAP2-BRAF fusions have a dimerisation domain that paradoxically activates the mitogen-activated protein kinase pathway, resulting in hyperproliferation if first-generation or second-generation BRAF inhibitors are used.

- The efficacy of third-generation combination of BRAF and MEK inhibitors looks promising in BRAF fusions in preclinical studies. 
third-generation BRAF inhibitors in combination with MEK inhibitors. $^{11}$

\section{Acknowledgments Thomas Botton}

Contributors All authors were involved in the patient's care. The manuscript was drafted by SMC, ML and MB, with critical appraisal by CMK. The final version has been approved by all authors.

Funding The authors have not declared a specific grant for this research from any funding agency in the public, commercial or not-for-profit sectors.

Competing interests None declared.

Patient consent for publication Obtained.

Provenance and peer review Not commissioned; externally peer reviewed.

Open access This is an open access article distributed in accordance with the Creative Commons Attribution Non Commercial (CC BY-NC 4.0) license, which permits others to distribute, remix, adapt, build upon this work non-commercially, and license their derivative works on different terms, provided the original work is properly cited and the use is non-commercial. See: http://creativecommons.org/ licenses/by-nc/4.0/.

\section{ORCID iD}

Sonya Minmin Chew http://orcid.org/0000-0003-1306-0822

\section{REFERENCES}

1 Melanoma cancer Factsheet, National cancer registry Ireland. Available: https://www. ncri.ie/sites/ncri/files/factsheets/Factsheet\%20melanoma.pdf

2 Elder DE, Bastian BC, Cree IA, et al. The 2018 World Health organization classification of cutaneous, mucosal, and uveal melanoma: detailed analysis of 9 distinct subtypes defined by their evolutionary pathway. Arch Pathol Lab Med 2020;144:500-22.

3 Hutchinson KE, Lipson D, Stephens PJ, et al. BRAF fusions define a distinct molecular subset of melanomas with potential sensitivity to MEK inhibition. Clin Cancer Res 2013;19:6696-702.

4 Waelchli R, Aylett SE, Atherton D, et al. Classification of neurological abnormalities in children with congenital melanocytic naevus syndrome identifies magnetic resonance imaging as the best predictor of clinical outcome. Br J Dermatol 2015;173:739-50.

5 Lu H, Villafane N, Dogruluk T, et al. Engineering and functional characterization of fusion genes identifies novel oncogenic drivers of cancer. Cancer Res 2017;77:3502-12.

6 Shalin SC. A review of kinase fusions in melanocytic tumors. Lab Invest 2017;97:158-65.

7 Turner JA, Bemis JGT, Bagby SM, et al. BRAF fusions identified in melanomas have variable treatment responses and phenotypes. Oncogene 2019:38:1296-308.

8 Johnson DB, Nebhan CA, Noel MS. MEK inhibitors in non-V600 BRAF mutations and fusions. Oncotarget 2020;11:3900-3.

9 Menzer C, Menzies AM, Carlino MS, et al. Targeted therapy in advanced melanoma with rare BRAF mutations. J Clin Oncol 2019;37:3142-51.

10 Menzies AM, Yeh I, Botton T, et al. Clinical activity of the MEK inhibitor trametinib in metastatic melanoma containing BRAF kinase fusion. Pigment Cell Melanoma Res 2015;28:607-10.

11 Botton T, Talevich E, Mishra VK, et al. Genetic heterogeneity of BRAF fusion kinases in melanoma affects drug responses. Cell Rep 2019;29:573-88.

Copyright 2021 BMJ Publishing Group. All rights reserved. For permission to reuse any of this content visit

https://www.bmj.com/company/products-services/rights-and-licensing/permissions/

BMJ Case Report Fellows may re-use this article for personal use and teaching without any further permission.

Become a Fellow of BMJ Case Reports today and you can:

- Submit as many cases as you like

- Enjoy fast sympathetic peer review and rapid publication of accepted articles

- Access all the published articles

Re-use any of the published material for personal use and teaching without further permission

Customer Service

If you have any further queries about your subscription, please contact our customer services team on +44 (0) 2071111105 or via email at support@bmj.com.

Visit casereports.bmj.com for more articles like this and to become a Fellow 